\title{
Is It All About the Data? How Extruded Polystyrene Escaped Single-Use Plastic Directive Market Restrictions
}

\author{
Maria Del Camino Troya, Orla-Peach Power and Kathrin Kopke* \\ Centre for Marine and Renewable Energy, Environmental Research Institute, University College Cork, Cork, Ireland
}

OPEN ACCESS

Edited by:

Kum Fai Yuen,

Nanyang Technological University,

Singapore

Reviewed by:

Rogerio Portantiolo Manzolli,

Costa University Corporation,

Colombia

*Correspondence: Kathrin Kopke

k.kopke@ucc.ie

Specialty section:

This article was submitted to

Marine Affairs and Policy,

a section of the journal

Frontiers in Marine Science

Received: 18 November 2021

Accepted: 20 December 2021

Published: 14 February 2022

Citation:

Troya MDC, Power O-P and

Kopke K (2022) Is It All About the Data? How Extruded Polystyrene Escaped Single-Use Plastic Directive

Market Restrictions.

Front. Mar. Sci. 8:817707.

doi: 10.3389/fmars.2021.817707
The Single-Use Plastics Directive (EU) 72/2019/904 is the main legislation governing plastic pollution, inclusive of marine plastic pollution in the European Union (EU). The Directive has issued market restrictions on several single-use plastic products which contribute to marine plastic pollution, including foamed polystyrene products made of expanded polystyrene (EPS). However, extruded polystyrene (XPS) which is commonly used in the same single-use plastics products as EPS has been omitted from the market placement restrictions within the scope of the Directive. This has subsequently compromised the Single-Use Plastics Directive's effectiveness for reducing marine plastic pollution and hinders the efforts of related EU instruments such as the Marine Strategy Framework Directive, Descriptor 10 toward achieving Good Environmental Status across the marine environment in the EU. This paper provides some background on EPS and XPS, and discusses plastic pollution policy making in the EU, while further addressing the role of quantitative data in the European Joint Research Centre's Technical Report on Top Marine Beach Litter Items in the EU for the formulation of policy regulating foamed polystyrene derived marine plastic pollution. We also provide an overview of how the communication gaps in the polymer science nomenclature for polystyrene may have contributed to the development of misnomers for extruded and EPS, consequently compromising necessary data gathering efforts. Our perspective hopes to incite conversations on communication gaps between scientists and policy makers and emphasise the need for gathering quantitative disaggregated data on the foamed polystyrene market to inform European plastic pollution legislation adequately.

Keywords: marine plastic pollution, single-use plastics directive, extruded polystyrene, expanded polystyrene, MSFD

\section{INTRODUCTION}

International legal, policy, and management interventions are being implemented to mitigate and reduce the impacts of marine plastic pollution (Chen, 2015; Gago et al., 2016; Black et al., 2019a), these include EU legal and policy instruments that can reduce the influx of plastic into the marine and wider environment; specifically, the EU Action Plan for the Circular Economy and the SingleUse Plastics Directive (EU) 72 2019/904 (SUP Directive) (Black et al., 2019b). Foamed polystyrene (PS), specifically expanded polystyrene (EPS) and extruded polystyrene (XPS) products have been widely reported as prominent marine litter items (Eriksen et al., 2014; Fok and Cheung, 2015; Addamo et al., 2017; European Commission, 2018; Jang et al., 2018; Thaysen et al., 2018). Low recycling rates in Europe and the characteristics of foamed PS, particularly its persistence in the 
environment, means that it could disproportionately contribute to marine pollution and broader environmental impacts (AlOdaini and Kannan, 2016; Chaukura et al., 2016; Turner, 2020).

Expanded polystyrene and extruded polystyrene are commonly used in many different applications including disposable packaging, packing for equipment (Thompsett et al., 1995; Issam et al., 2009; Chaukura et al., 2016), fast food containers (Cassidy and Elyashiv-Barad, 2007; Al-Odaini and Kannan, 2016; Gallego-Schmid et al., 2019; Kedzierski et al., 2020), aquaculture equipment (Eriksen et al., 2014; Al-Odaini and Kannan, 2016), and construction and insulation materials (Carignan et al., 2012; Jondreville et al., 2017; Abdallah et al., 2018). Both EPS and XPS have high production and consumption rates, which are projected to further increase over time (Black et al., 2019a), which in turn increases the potential for XPS and EPS to become marine litter (Jambeck et al., 2015; Chaukura et al., 2016). Foamed PS plastics are particularly harmful in comparison to other plastics due to additives (e.g., hexabromocyclododecane) which can leach into marine environments over time (Lithner et al., 2011; Al-Odaini et al., 2015; Rani et al., 2015; Al-Odaini and Kannan, 2016; Abdallah et al., 2018; Turner, 2021). The toxicological effects of foamed PS on marine life are well documented within the scientific literature (Deng et al., 2018; Lu et al., 2018; Bradney et al., 2019) and foamed PS microplastics have been found to cause oxidative stress and inflammatory responses on lung tissue, adversely affecting human respiratory health (Lim et al., 2019; Dong et al., 2020).

Addressing marine plastic pollution through legislation is challenging (Black et al., 2019b) and while Article 5 of the SUP Directive, in recital 29 specifically emphasises that "the aim of the Directive is to protect the environment and human health" (European Commission, 2019a), XPS has not been incorporated in associated market placement restrictions of SUP products. In this perspective article, the authors argue that the scarcity of available disaggregated data for XPS production, use, recycling, and waste management has not only contributed to a limited understanding of its impact on the marine environment, but that the incomplete quantification of XPS in marine litter surveys (e.g., Addamo et al., 2017) may have contributed to the material not being included within the scope of the SUP Directive. We present the perspective that increasing the availability of disaggregated data for XPS within the foamed polystyrene SUP market, and developing and adopting harmonisation of terminology for foamed PS types is essential to facilitate clear communication about, and understanding of the extent and impact XPS marine litter poses, which in turn benefits associated mitigation of marine plastic pollution.

\section{EXPANDED POLYSTYRENE AND EXTRUDED POLYSTYRENE OVERVIEW}

Polystyrene is a synthetic thermoplastic made from the polymerisation of the styrene monomer and has been commercialised since 1931 (Farrelly and Shaw, 2017; Lassen et al., 2019). It is one of the most widely used plastics in the
EU, with European production estimated at 2 million tonnes in 2018 and with a demand of 1.5 million tonnes for EPS resin (PlasticsEurope, 2019). EPS and XPS are rigid, closed cell foamed types of PS consisting of $98 \%$ air (Kaemmerlen et al., 2010). The key differences between EPS and XPS are in the production method, additives used (e.g., benzene-trisamide, pentane, hexabromocyclododecane, MAXITHEN HP 781700 TR), and cell structure (Gabriel-Chemie, 2010; Aksit et al., 2019). EPS is produced from pre-expanded PS beads in three distinct stages; (1) pre-expansion, (2) conditioning, and (3) moulding (Chen et al., 2015; Lassen et al., 2019). The production of XPS differs in that solid PS crystals are mixed with additives and a blowing agent (fluorocarbon or non-fluorocarbon), which are heated under controlled conditions to produce a thick liquid (Copcutt and Croft, 1964; Lassen et al., 2019). At a cellular structure level, XPS is completely closed with no cavities making it more resistant to pressure, humidity (Lassen et al., 2019), and degradation (Al-Odaini and Kannan, 2016; Chaukura et al., 2016).

Despite EPS and XPS being technically recyclable (MacKerron, 2015; Al-Odaini and Kannan, 2016; GallegoSchmid et al., 2019; Lassen et al., 2019), research indicates that recovery potential globally is low due to end-of-life waste management limitations (Tan and Khoo, 2005; Aarnio and Hämäläinen, 2008; Barnes et al., 2011; MacKerron, 2015; Gallego-Schmid et al., 2019; PlasticsEurope, 2019). Barriers to recycling of EPS and XPS include a lack of public awareness (Conversio, 2018; de Oliveira et al., 2019; Lassen et al., 2019), heterogeneity in waste management infrastructure across Europe, and the high costs associated with transport and subsequent treatment processes required to produce suitable recovered EPS and XPS materials for reuse in commercial markets (Aarnio and Hämäläinen, 2008; MacKerron, 2015; Razza et al., 2015; Chaukura et al., 2016; Carey, 2017; Lassen et al., 2019).

\section{EXPANDED POLYSTYRENE AND EXTRUDED POLYSTYRENE NOMENCLATURE}

Polystyrene is the semi-systematic or trivial name for the monomer poly (1-phenylethene) and is widely used across academia, industry, and official and regulatory documents (European Commission, 2019a). Polymer nomenclature has an impact on consumers, intellectual property protection, commercial, educational, and scientific domains. The Polymer Division of the International Union of Pure and Applied Chemistry (IUPAC) is responsible for the universal terminology definitions in polymer science by issuing recommendations on definitions through a rigorous scientifically validated process (Chan et al., 2017). The European Chemicals Agency (ECHA) and Regulation (EC) No 1907/2006 (REACH) recommends the use of IUPAC nomenclature for polymers and monomers (ECHA, 2012). These definitions as such, serve as a reliable source of information on polymer nomenclature for journalism, industry, and education (Chan et al., 2017; Mormann et al., 2017). 
International Union of Pure and Applied Chemistry recommends that the use of semi-systematic or trivial names should be kept to a minimum to avoid confusion and misnomers, which has occurred for EPS and XPS (International Union of Pure and Applied Chemistry [IUPAC], 2008; Mormann et al., 2017). "Styrofoam," a trademark invented by Dow Chemical in 1941 for a blue coloured type of XPS used in building insulation, is a widespread and commonly used misnomer for EPS or PS in general (Farrelly and Shaw, 2017; Wagner, 2020). As early as 1960 this misnomer also appeared in the academic literature, most surprisingly, in a study commissioned by the Dow Chemical Company themselves, where EPS is referred to as Styrofoam (Waite, 1960). The relative widespread use of the Styrofoam misnomer for PS and EPS may have contributed to the limited availability of disaggregated data on EPS and XPS in marine litter reports. We suggest that a harmonisation of terminology for foamed polystyrene which clearly differentiates between EPS and XPS should be adopted and supported to minimise confusion in regulatory, media, and academic environments. This will contribute to the adherence toward the EU Better Regulation Agenda, ensuring that a transparent and evidencebased approach is incorporated into one of the main pieces of legislation underpinning the EU Green Deal. This has been demonstrated, for example, in the pacific island state of Niue, which offers a standardised definition for plastic foam in its legislation and specifies that both, EPS and XPS, are included in market restriction measures (United Nations Environmental Programme [UNEP], 2018).

\section{EXPANDED POLYSTYRENE AND EXTRUDED POLYSTYRENE DATA AGGREGATION AND REPORTING}

In Europe, public reports and the scientific literature tend to either focus on PS or specifically on EPS (Ministry of Infrastructure and the Environment The Netherlands, 2016; Conversio, 2018; Lassen et al., 2019; Miljøstyrelsen, 2019) and do not offer disaggregated data for XPS. Plastics Europe reports indicate that PS and EPS together represented $6.4 \%$ of the recorded European resin demand in 2018 (PlasticsEurope, 2019), however, the authors have been unable to identify data relating to XPS, making it impossible to even begin to assess the impact of XPS products in the marine environment, or design waste management solutions to mitigate for them. The 2019 "Survey of Polystyrene Foam (EPS and XPS) in the Baltic Sea” commissioned by HELCOM presents results on EPS for marine litter surveys and indicates that the PRODCOM databases do not provide production data on EPS nor XPS, and products made from EPS and XPS are not registered in trade statistics (Lassen et al., 2019). Similarly, the JRC Technical Report on "Top Marine Beach Litter Items in Europe (JRC108181)" does not provide data on XPS and does not provide specific values for EPS (Addamo et al., 2017). This report is the scientific assessment through which the most frequent marine beach litter items found on EU beaches are identified, based on a harmonised data set from a series of beach litter surveys from 2016 (Addamo et al., 2017), and serves as the scientific basis for the Marine Strategy Framework Directive (MSFD) Descriptor 10 monitoring framework and for the SUP's market placement restriction list.

Based on the results from the JRC Technical Report, the SUP Directive establishes in Article 5 that "in view of the high prevalence of expanded polystyrene litter in the marine environment and the availability of alternatives, single-use food and beverage containers and cups for beverages made of expanded polystyrene should also be restricted" (European Commission, 2019a). An aggregated assessment of foamed PS products found on the EU's beaches is provided in the report and categories of aggregation for foamed plastics that are associated with EPS and XPS product applications are listed as foam pieces, cups and food packs, foam buoys, other plastic foam packaging. It is important to note that the report does not detail what type of foamed plastics constitute these categories and the only instance in which EPS is mentioned is within the context of fish-box EPS litter, while XPS is not referred to.

The Impact Assessment (IA) carried out by the European Commission (EC) for the proposal of the SUP Directive developed a quantitative model based on the JRC data to determine the top 10 single-use plastic items that should be under the scope of the Directive (Elliott et al., 2018). It is not clear how the IA concluded that EPS single-use food containers and cups be included on this list, but it is of interest to note that EPS and XPS are referred to as one type of product. One might speculate that producers may shift away from expanded/extruded polystyrene (EPS/XPS) food containers, for example, as these are currently difficult to recycle. If this occurred then one might expect a corresponding reduction in littering of EPS/XPS" (Elliott et al., 2018). The IA does not detail the methodology for data modelling and interpretation of foamed PS litter, nor does it detail the categorisation of only EPS as a top marine beach litter item and not XPS. As this report provides the scientific assessment for SUP products subject to regulation and waste management initiatives such as the SUP Directive, it could be inferred that XPS not being included within the market restrictions Annex of the Directive is due to it not being quantified within the JRC Technical Report (European Commission, 2019a). It is possible that the tendency to aggregate EPS and XPS data is driven by the presumption that results would apply to both styrenic polymers when placed under the same conditions (Lassen et al., 2019), and may therefore not require independent studies. However, it would stand to reason that XPS would therefore, by association, have been included in the SUP Directive's Annex of listed materials. Furthermore, there are clearly identifiable environmental and human health pressures associated with foamed PS marine litter and following the precautionary principle which underpins EU environmental law would merit for both EPS and XPS single-use products to be subject to market placement restrictions.

\section{DISCUSSION}

The MSFD (2008/56/EC) and the Water Framework Directive (WFD) (2000/60/EC) are the main legislative instruments through which the EU manages the environmental protection 
of marine and aquatic resources (European Commission, 2000, 2008; Black et al., 2019b). The MSFD establishes a regulatory strategy through which Member States must ensure Good Environmental Status (GES) in their marine waters and establishes a legal commitment toward marine plastic pollution mitigation (e.g., Descriptor 10). Furthermore, through Decision (EU) 2017/848 the EC establishes that Member States must establish and define threshold values for Descriptor 10 considering the precautionary principle. In the case of XPS marine litter, the lack of quantitative data will not enable such threshold values to be established and hinders the development of associated mitigation measures to contribute to achieving GES by Member States.

The legal framework regulating plastic production and addressing its contribution to marine pollution in the EU is established through the SUP Directive and its supporting strategies, the European Strategy for Plastics in a Circular Economy, and the EU Action Plan for a Circular Economy.

Article 5 of the SUP Directive establishes market restrictions developed under the premise of the precautionary principle, which would require sufficient scientific evidence to warrant the restriction of a product, which is evidenced through numeral 7; "this Directive should cover only those single-use plastic products that are found the most on the beaches in the Union." Since there is not data to give a quantitative assessment of the presence of XPS marine litter on European beaches, it could be assumed that XPS marine litter may have fallen out of the scope of the SUP Directive. However, anecdotal evidence (Thornberry, 2020) signals the widespread use of XPS in SUP containers in food outlets, similarly to EPS application. Furthermore, the Packaging and Packaging Waste Directive (PPW) (94/62/EC), updated through Directive 2018/852 and the Waste Framework Directive (WFD) (2008/98/EC), reiterates through Article 1 in its 2018 amendments that Member States should prioritise packaging waste prevention within waste management plans and emphasises that the presence of packaging waste in the marine environment supports prevention strategies (European Commission, 2019b). It is in this context, that the inclusion of XPS single-use food packaging products in the market restriction measures of the SUP Directive, would also better equip Member States to meet relevant targets on waste prevention. Whilst these Directives establish a regulatory framework to mitigate marine plastic pollution and achieve GES in the EU's marine waters in compliance with the MSFD, the effectiveness of such measures may be compromised as XPS products are not explicitly included within the market restrictions established under the SUP Directive.

As an evaluation of the SUP Directive is not due till July 2027, any potential inclusion of XPS in the Directives market restrictions is not possible within a reasonable timeframe, despite the compelling scientific evidence that the presence of XPS in the marine environment may have significant environmental and potential health impacts. Furthermore, there is evidence that the legal loopholes in the SUP Directive may allow for certain types of single-use plastics such as XPS to continue being used as a replacement for EPS. For example, the German company Papstar has sent out a document offering alternatives for the products banned by the SUP and offers XPS as a replacement for banned EPS products (Papstar GmbH, 2021). Similarly, the Dutch company Abena has released a catalogue of alternative products to replace those banned by the SUP and indicates that XPS is still allowed and will continue to commercialise its XPS products (Abena, 2021). A similar phenomenon has been observed in the United States in which only 9.9\% of bans included XPS (Eunomia, 2018). It was observed that in communities where EPS was banned, retailers switched over to XPS food-ware as a replacement (Wagner, 2020).

Member States have begun transposition of the SUP Directive and in accordance with Annex B, only EPS single-use containers are being banned (France, ${ }^{1}$ Germany, ${ }^{2}$ and Spain ${ }^{3}$ ). In addition to a future inclusion of XPS within Annex B of an evaluated SUP Directive, Member States themselves should be encouraged and supported in implementing national regulations that impose associated XPS market placement restrictions prior to the 2027 SUP evaluation, to ensure Member States and the EU can meet plastic waste reduction targets toward reaching GES as required by the MSFD. Under Article 129 (1) of REACH, Member States can enact measures for protection of the environment, provided that such measures protect human health and/or the environment (Kentin and Kaarto, 2018; REACH). This has been successfully demonstrated through the market bans of microbeads in EU countries before the associated ECHA restriction dossier was released. Through EU notifications, the following countries advised the Commission of its national regulations implementing market placement restrictions on cosmetic products containing microbeads; France through 2016/543/F $\mathrm{F}^{4}$ Sweden ${ }^{5}$ through 2017/284/S; the United Kingdom through 2017/353/UK ${ }^{6}$; Belgium through $2017 / 465 / \mathrm{B}^{7}$; and Italy through $2018 / 258 / 1{ }^{8}$ in addition to Finland, Iceland, Ireland, Luxemburg, and Norway implementing relevant market bans (Dauvergne, 2018; Kentin and Kaarto, 2018). Environmental policies and legal instruments have been shown to have a higher chance of success, if public health is considered (Mederake and Knoblauch, 2019) and public support is provided (Black et al., 2019a). This requires clear communication and widespread understanding of XPS marine litter, including associated environmental and potential human health implications. This

\footnotetext{
${ }^{1}$ LOI n ${ }^{\circ}$ 2020-105 du 10 février 2020 relative à la lutte contre le gaspillage et à l'économie circulaire.

${ }^{2}$ Drucksache 575/20 Verordnung über das Verbot des Inverkehrbringens von bestimmten Einwegkunststoffprodukten und von Produkten aus oxo-abbaubarem Kunststoff (Einwegkunststoffverbotsverordnung - EWKVerbotsV).

${ }^{3}$ Proyecto de Ley de Residuos y Suelos Contaminados 2021.

${ }^{4}$ Décret no 2017-291 du 6 mars 2017 relatif aux conditions de mise en oeuvre de l'interdiction de mise sur le marché des produits cosmétiques rincés à usage d'exfoliation ou de nettoyage comportant des particules plastiques solides et des bâtonnets ouatés à usage domestique dont la tige est en plastique.

${ }^{5}$ Förordning om ändring i förordningen (1998:944) om förbud m.m. i vissa fall i samband med hantering, införsel och utförsel av kemiska produkter.

${ }^{6}$ The Environmental Protection (Microbeads) (England) Regulations 2017.

${ }^{7}$ Ontwerp van sectoraal akkoord ter ondersteuning van het vervangen van microplastics in consumptieproducten.

${ }^{8}$ Divieto di commercializzazione dei bastoncini per la pulizia delle orecchie nonbiodegradabili e non-compostabili e dei prodotti cosmetici da risciacquo ad azione esfoliante o detergente contenenti microplastiche.
} 
can only be achieved, if disaggregated data for XPS within the foamed PS SUP market, and for relevant environmental monitoring, surveys and assessments is collated, clearly labelled, and accessible to underpin informed discussions and decision making in Member States.

\section{DATA AVAILABILITY STATEMENT}

The original contributions presented in the study are included in the article/supplementary material, further inquiries can be directed to the corresponding author.

\section{AUTHOR CONTRIBUTIONS}

MT, O-PP, and KK contributed on the conception of the perspective. MT wrote the first draft of the manuscript. All

\section{REFERENCES}

Aarnio, T., and Hämäläinen, A. (2008). Challenges in packaging waste management in the fast food industry. Resour. Conserv. Recycl. 52, 612-621. doi: 10.1016/j.resconrec.2007.08.002

Abdallah, M. A.-E., Sharkey, M., Berresheim, H., and Harrad, S. (2018). Hexabromocyclododecane in polystyrene packaging: a downside of recycling? Chemosphere 199, 612-616. doi: 10.1016/j.chemosphere.2018.02.084

Abena (2021). Alternative to Banned Plastic Products. Available online at: https://www.abena-reseller.nl/wp-content/uploads/2021/04/plastic-abenamilieu-producten.pdf (accessed September 2021).

Addamo, A., LaRoche, P., and Hanke, G. (2017). Top Marine Beach Litter Items in Europe, EUR 29249. Luxembourg: Publications Office of the European Union. doi: $10.2760 / 496717$

Aksit, M., Zhao, C., Klose, B., Kreger, K., Schmidt, H.-W., and Altstädt, V. (2019). Extruded polystyrene foams with enhanced insulation and mechanical properties by a benzene-trisamide-based additive. Polymers (Basel) 11:268. doi: 10.3390/polym 11020268

Al-Odaini, N. A., and Kannan, N. (2016). "Sequestration and redistribution of emerging and classical POPS by polystyrene: an aspect overlooked?, in Persistent Organic Chemicals in the Environment: Status and Trends in the Pacific Basin Countries I Contamination Status, eds B. G. Loganathan, J. S. Khim, P. R. S. Kodavanti, and S. Masunaga (Washington, DC: ACS Publication), 219-236. doi: 10.1021/bk-2016-1243.ch010

Al-Odaini, N. A., Shim, W. J., Han, G. M., Jang, M., and Hong, S. H. (2015). Enrichment of hexabromocyclododecanes in coastal sediments near aquaculture areas and a wastewater treatment plant in a semi-enclosed bay in South Korea. Sci. Total Environ. 505, 290-298. doi: 10.1016/j.scitotenv.2014.10. 019

Barnes, M., Chan-Halbrendt, C., Zhang, Q., and Abejon, N. (2011). Consumer preference and willingness to pay for non-plastic food containers in Honolulu, USA. J. Environ. Prot. (Irvine. Calif). 02, 1264-1273. doi: 10.4236/jep.2011. 29146

Black, J. E., Kopke, K., and O’Mahony, C. (2019a). Towards a circular economy: using stakeholder subjectivity to identify priorities, consensus, and conflict in the Irish EPS/XPS Market. Sustainability 11:6834. doi: 10.3390/su1123 6834

Black, J. E., Kopke, K., and O’Mahony, C. (2019b). A trip upstream to mitigate marine plastic pollution - A perspective focused on the MSFD and WFD. Front. Mar. Sci. 6:689. doi: 10.3389/fmars.2019.00689

Bradney, L., Wijesekara, H., Palansooriya, K. N., Obadamudalige, N., Bolan, N. S., Ok, Y. S., et al. (2019). Particulate plastics as a vector for toxic trace-element uptake by aquatic and terrestrial organisms and human health risk. Environ. Int. 131:104937. doi: 10.1016/j.envint.2019.104937 authors wrote the sections of the manuscript, contributed to the manuscript revision, and read and approved the submitted version.

\section{FUNDING}

This work has been completed as part of the OceanWise project EAPA_252/2016 funded under INTERREG Atlantic Area.

\section{ACKNOWLEDGMENTS}

We would like to thank Seabird and the OceanWise consortium for the data that informed this perspective.

Carey, J. (2017). On the brink of a recycling revolution? Proc. Natl. Acad. Sci. U.S.A. 114, 612-616. doi: 10.1073/pnas.1620655114

Carignan, C. C., Abdallah, M. A.-E., Wu, N., Heiger-Bernays, W., McClean, M. D., Harrad, S., et al. (2012). Predictors of Tetrabromobisphenol-A (TBBP-A) and Hexabromocyclododecanes (HBCD) in Milk from Boston Mothers. Environ. Sci. Technol. 46, 12146-12153. doi: 10.1021/es30 2638d

Cassidy, K., and Elyashiv-Barad, S. (2007). US FDA's revised consumption factor for polystyrene used in food-contact applications. Food Addit. Contam. 24, 1026-1031. doi: 10.1080/02652030701313797

Chan, C. H., Fellows, C. M., Hess, M., Hiorns, R. C., Hoven, V. P., Russell, G. T., et al. (2017). The contribution of IUPAC to polymer science education. J. Chem. Educ. 94, 1618-1628. doi: 10.1021/acs.jchemed.6b0 0800

Chaukura, N., Gwenzi, W., Bunhu, T., Ruziwa, D. T., and Pumure, I. (2016). Potential uses and value-added products derived from waste polystyrene in developing countries: a review. Resour. Conserv. Recycl. 107, 157-165. doi: 10.1016/j.resconrec.2015.10.031

Chen, C.-L. (2015). "Regulation and management of marine litter," in Marine Anthropogenic Litter, eds M. Bergmann, L. Gutow, and M. Klages (Cham: Springer International Publishing), 395-428. doi: 10.1007/978-3-319-165 10-3_15

Chen, W., Hao, H., Hughes, D., Shi, Y., Cui, J., and Li, Z.-X. (2015). Static and dynamic mechanical properties of expanded polystyrene. Mater. Des. 69, 170-180. doi: 10.1016/j.matdes.2014.12.024

Conversio (2018). Post Consumer EPS Waste Generation and Management in European Countries 2017. Ludwigshafen am Rhein: BASF SE

Copcutt, D. P. T., and Croft, P. W. (1964). Paper 8: polyurethane and polystyrene as thermal insulants. Proc. Inst. Mech. Eng. Conf. Proc. 179, 72-79. doi: 10.1243/ PIME_CONF_1964_179_032_02

Dauvergne, P. (2018). The power of environmental norms: marine plastic pollution and the politics of microbeads. Env. Polit. 27, 579-597. doi: 10.1080/09644016. 2018.1449090

de Oliveira, C. T., Luna, M. M. M., and Campos, L. M. S. (2019). Understanding the Brazilian expanded polystyrene supply chain and its reverse logistics towards circular economy. J. Clean. Prod. 235, 562-573. doi: 10.1016/j.jclepro.2019.06. 319

Deng, Y., Zhang, Y., Qiao, R., Bonilla, M. M., Yang, X., Ren, H., et al. (2018). Evidence that microplastics aggravate the toxicity of organophosphorus flame retardants in mice (Mus musculus). J. Hazard. Mater. 357, 348-354. doi: 10. 1016/j.jhazmat.2018.06.017

Dong, C.-D., Chen, C.-W., Chen, Y.-C., Chen, H.-H., Lee, J.-S., and Lin, C.H. (2020). Polystyrene microplastic particles: in vitro pulmonary toxicity assessment. J. Hazard. Mater. 385:121575. doi: 10.1016/j.jhazmat.2019.121575 
ECHA (2012). Guidance for Monomers and Polymers. Available online at: http://echa.europa.eu/documents/10162/13632/polymers_en.pdf (accessed May 2020).

Elliott, T., Burgess, R., Darrah, C., Elliott, L., Chris, S., Bapasola, A., et al. (2018). Assessment of Measures to Reduce Marine Litter from Single use Plastics. Part of European Commission Study Contract. Luxembourg: European Commission, doi: $10.2779 / 500175$

Eriksen, M., Lebreton, L. C. M., Carson, H. S., Thiel, M., Moore, C. J., Borerro, J. C., et al. (2014). Plastic pollution in the world's oceans: more than 5 trillion plastic pieces weighing over 250,000 tons afloat at sea. PLoS One 9:e111913. doi: 10.1371/journal.pone.0111913

Eunomia (2018). Assessment of Measures to Reduce Marine Litter from Single use Plastics: Final Report and Annex. Available online at: https://ec.europa.eu/ environment/pdf/waste/Study_sups.pdf. (accessed May 2020).

European Commission (2000). Directive 2000/60/EC of the European parliament and of the council of 23 october 2000 establishing a framework for community action in the field of water policy. Off. J. Eur. Comm. 327, 1-72.

European Commission (2008). Directive 2008/56/EC of the European parliament and of the council of 17 june 2008 establishing a framework for community action in the field of marine environmental policy (marine strategy framework directive). Off. J. Eur. Comm. 125, 1-27.

European Commission (2018). Commission Staff Working Document Impact Assessment for the Proposal for a Directive of the European Parliament and of the Council on the Reduction of the Impact of Certain Plastic Products on the Environment. SWD(2018)254 final. Luxembourg: European Commission.

European Commission (2019a). Directive (EU) 2019/904 of the European Parliament and of the Council of 5 June 2019 on the Reduction of the Impact of Certain Plastic Products on the Environment. Available online at: http://data. europa.eu/eli/dir/2019/904/oj (accessed April, 2020).

European Commission (2019b). Directive 2008/98/EC of the European Parliament and of the council of 19 november 2008 on waste and repealing certain Directives. Off. J. Eur. Comm. 312, 1-59.

Farrelly, T. A., and Shaw, I. C. (2017). "Polystyrene as hazardous household waste," in Household Hazardous Waste Management, ed. D. Mmereki (London: InTech). doi: 10.5772/65865

Fok, L., and Cheung, P. K. (2015). Hong Kong at the pearl river estuary: a hotspot of microplastic pollution. Mar. Pollut. Bull. 99, 112-118. doi: 10.1016/j.marpolbul. 2015.07.050

Gabriel-Chemie (2010). Additive and Colour Preparations for Extruded Polystyrene Foams. Available online at: https://www.gabriel-chemie.com/downloads/ folder/XPS-foam_en.pdf (accessed August 2021).

Gago, J., Galgani, F., Maes, T., and Thompson, R. C. (2016). Microplastics in seawater: recommendations from the marine strategy framework directive implementation process. Front. Mar. Sci. 3:219. doi: 10.3389/fmars.2016.00219

Gallego-Schmid, A., Mendoza, J. M. F., and Azapagic, A. (2019). Environmental impacts of takeaway food containers. J. Clean. Prod. 211, 417-427. doi: 10.1016/ j.jclepro.2018.11.220

International Union of Pure and Applied Chemistry [IUPAC] (2008). Compendium of Polymer Terminology and Nomenclature, IUPAC Recommendations 2008. Research Triangle, NC: IUPAC, doi: 10.1515/ci.2009.31.4.32

Issam, A. M., Poh, B. T., Abdul Khalil, H. P. S., and Lee, W. C. (2009). Adhesion properties of adhesive prepared from waste polystyrene. J. Polym. Environ. 17, 165-169. doi: 10.1007/s10924-009-0134-y

Jambeck, J. R., Geyer, R., Wilcox, C., Siegler, T. R., Perryman, M., Andrady, A., et al. (2015). Plastic waste inputs from land into the ocean. Science 347, 768-771. doi: 10.1126/science. 1260352

Jang, M., Shim, W. J., Han, G. M., Song, Y. K., and Hong, S. H. (2018). Formation of microplastics by polychaetes (Marphysa sanguinea) inhabiting expanded polystyrene marine debris. Mar. Pollut. Bull. 131, 365-369. doi: 10.1016/j. marpolbul.2018.04.017

Jondreville, C., Cariou, R., Travel, A., Belhomme, L.-J., Dervilly-Pinel, G., Le Bizec, B., et al. (2017). Hens can ingest extruded polystyrene in rearing buildings and lay eggs contaminated with hexabromocyclododecane. Chemosphere 186, 62-67. doi: 10.1016/j.chemosphere.2017.07.117

Kaemmerlen, A., Vo, C., Asllanaj, F., Jeandel, G., and Baillis, D. (2010). Radiative properties of extruded polystyrene foams: predictive model and experimental results. J. Quant. Spectrosc. Radiat. Transf. 111, 865-877. doi: 10.1016/j.jqsrt. 2009.11.018
Kedzierski, M., Lechat, B., Sire, O., Le Maguer, G., Le Tilly, V., and Bruzaud, S. (2020). Microplastic contamination of packaged meat: occurrence and associated risks. Food Packag. Shelf Life 24:100489. doi: 10.1016/j.fpsl.2020. 100489

Kentin, E., and Kaarto, H. (2018). An EU ban on microplastics in cosmetic products and the right to regulate. Rev. Eur. Comp. Int. Environ. Law 27, 254-266. doi: $10.1111 /$ reel.12269

Lassen, C., Warming, M., Kjølholt, J., Line Geest Jakobsen, N. V., Novichkov, B., Strand, J., et al. (2019). Survey of polystyrene foam (EPS and XPS) in the Baltic Sea. Lyngby: Danish Fisheries Agency

Lim, S. L., Ng, C. T., Zou, L., Lu, Y., Chen, J., Bay, B. H., et al. (2019). Targeted metabolomics reveals differential biological effects of nanoplastics and nanoZnO in human lung cells. Nanotoxicology 13, 1117-1132. doi: 10.1080/ 17435390.2019.1640913

Lithner, D., Larsson, A, and Dave, G. (2011). Environmental and health hazard ranking and assessment of plastic polymers based on chemical composition. Sci. Total Environ. 409, 3309-3324. doi: 10.1016/j.scitotenv.2011. 04.038

Lu, L., Wan, Z., Luo, T., Fu, Z., and Jin, Y. (2018). Polystyrene microplastics induce gut microbiota dysbiosis and hepatic lipid metabolism disorder in mice. Sci. Total Environ. 631-632, 449-458. doi: 10.1016/j.scitotenv.2018. 03.051

MacKerron, C. B. (2015). Waste and Opportunity 2015: Environmental Progress and Challenges in Food, Beverage, and Consumer Goods Packaging. Luxembourg: European Commission.

Mederake, L., and Knoblauch, D. (2019). Shaping EU plastic policies: the role of public health vs. environmental arguments. Int. J. Environ. Res. Public Health 16:3928. doi: 10.3390/ijerph 16203928

Miljøstyrelsen (2019). Nyt Liv Til Postconsumer Isolering og Emballager i EPS. Copenhagen: Miljøstyrelsen.

Ministry of Infrastructure and the Environment The Netherlands (2016). HBCDD in EPS/XPS Waste in the Netherlands Inventory of size and Value. Available online at: http://chm.pops.int/Portals/0/download.aspx?d=UNEP-POPSNPOPS-INVENT-HBCDD-Netherlands-20161222.English.pdf (accessed June 2020).

Mormann, W., Hellwich, K.-H., Chen, J., and Wilks, E. S. (2017). Preferred names of constitutional units for use in structure-based names of polymers (IUPAC Recommendations 2016). Pure Appl. Chem. 89, 1695-1736. doi: 10.1515/pac2016-0502

Papstar GmbH (2021). Single Use Plastics Directive (SUPD) - EU Einwegkunststoffverbotsverordnung - Nationale Umsetzung. Available online at: https://www.papstar.com/fileadmin/user_upload/einmalgeschirr/SUPD_ Plastikverbot_2021_01.pdf (accessed July 3, 2021).

PlasticsEurope (2019). Plastics - the Facts 2019. An Analysis of European Plastics Production, Demand and Waste Data. Düsseldorf: PlasticsEurope.

Rani, M., Shim, W. J., Han, G. M., Jang, M., Al-Odaini, N. A., Song, Y. K., et al. (2015). Qualitative analysis of additives in plastic marine debris and its new products. Arch. Environ. Contam. Toxicol. 69, 352-366. doi: 10.1007/s00244015-0224-x

Razza, F., Degli Innocenti, F., Dobon, A., Aliaga, C., Sanchez, C., and Hortal, M. (2015). Environmental profile of a bio-based and biodegradable foamed packaging prototype in comparison with the current benchmark. J. Clean. Prod. 102, 493-500. doi: 10.1016/j.jclepro.2015.04.033

Tan, R. B. H., and Khoo, H. H. (2005). Life cycle assessment of EPS and CPB inserts: design considerations and end of life scenarios. J. Environ. Manage. 74, 195-205. doi: 10.1016/j.jenvman.2004.09.003

Thaysen, C., Stevack, K., Ruffolo, R., Poirier, D., De Frond, H., DeVera, J., et al. (2018). Leachate from expanded polystyrene cups is toxic to aquatic invertebrates (Ceriodaphnia dubia). Front. Mar. Sci. 5:71. doi: 10.3389/fmars. 2018.00071

Thompsett, D. J., Walker, A., Radley, R. J., and Grieveson, B. M. (1995). Design and construction of expanded polystyrene embankments. Constr. Build. Mater. 9, 403-411. doi: 10.1016/0950-0618(95) 00069-0

Thornberry, M. (2020). Expanding the Knowledge Base of Expanded and Extruded Polystyrene: A Report. Available online at: https://repak.ie/images/uploads/ reports/Expanding_the_Knowledge_Base_of_Expanded_and_Extruded_ Polystyrene.pdf (accessed April 2020) 
Turner, A. (2020). Foamed polystyrene in the marine environment: sources, additives, transport, behavior, and impacts. Environ. Sci. Technol. 54, $10411-$ 10420. doi: 10.1021/acs.est.0c03221

Turner, A. (2021). Polystyrene foam as a source and sink of chemicals in the marine environment: an XRF study. Chemosphere 263:128087. doi: 10.1016/j. chemosphere.2020.128087

United Nations Environmental Programme [UNEP] (2018). Legal Limits on Single-Use Plastics and Microplastics: A Global Review of National Laws and Regulations. Available online at: https://wedocs.unep.org/20.500.11822/27113 (accessed April 2020)

Wagner, T. P. (2020). Policy instruments to reduce consumption of expanded polystyrene food service ware in the USA. Detritus 09, 11-26. doi: 10.31025/ 2611-4135/2020.13903

Waite, H. J. (1960). "Styrofoam (expanded polystyrene) insulation at low temperature," in Advances in Cryogenic Engineering, eds K. D. TimmerhausR, P. ReedA, and F. Clark (Boston, MA: Springer US), 230-234.
Conflict of Interest: The authors declare that the research was conducted in the absence of any commercial or financial relationships that could be construed as a potential conflict of interest.

Publisher's Note: All claims expressed in this article are solely those of the authors and do not necessarily represent those of their affiliated organizations, or those of the publisher, the editors and the reviewers. Any product that may be evaluated in this article, or claim that may be made by its manufacturer, is not guaranteed or endorsed by the publisher.

Copyright (c) 2022 Troya, Power and Kopke. This is an open-access article distributed under the terms of the Creative Commons Attribution License (CC BY). The use, distribution or reproduction in other forums is permitted, provided the original author(s) and the copyright owner(s) are credited and that the original publication in this journal is cited, in accordance with accepted academic practice. No use, distribution or reproduction is permitted which does not comply with these terms. 